\title{
PELAKSANAAN SUPERVISI AKADEMIK UNTUK MENINGKATKAN KOMPETENSI PEDAGOGIK GURU SMA
}

\author{
Paulus Joko Prayitno \\ SMAN 2 Bengkayang \\ Email:pjprayitno23@gmail.com
}

\begin{abstract}
Abstrak:
Pada kenyataan guru belum maksimal dalam mengelola pembelajaran. Penelitian ini bertujuan: untuk meningkatkan pelaksanaan supervisi Akademik dalam meningkatkan kemampuan pedagogik guru dalam melaksanakan pembelajaran di kelas. Metode penelitian yang digunakan adalah pendekatan deskriptif . Prosedur pelaksanaan penelitian terdiri dari tahap : (1) Perencanaan,(2) Pelaksanaan, (3) Observasi dan (4) Refleksi.Hasil penelitian menunjukkan bahwa : Pada siklus I kemampuan guru melaksanakan pembelajaran masih rendah hal ini dibuktikan dengan nilai akhir yang diperoleh setiap, dan nilai rata-rata kemampuan guru dari hasil observasi pembelajaran dimana guru yang memperoleh skor nilai 1 (kurang) dengan rentang nilai dibawah 55\% adalah 1 orang guru, skor nilai 2 (cukup) dengan rentang nilai 55\%-69\% adalah 10 orang guru, skor nilai 3 (baik) rentang nilai 70\%-85\% adalah 2 orang guru, dan tidak ada guru yang memperoleh skor nilai 4 (sangat baik).Pada siklus II terjadi peningkatan kemampuan mengajar guru yang dari siklus I, pada siklus guru yang memperoleh skor nilai 2 (cukup) dengan rentang nilai 55\%-69\% adalah 3 orang, dan skor nilai 3 (baik) rentang nilai 70\%-.85\% adalah 10 orang guru, dan tidak ada guru yang memperoleh skor nilai 1 (kurang) dan skor nilai 4 (sangat baik). Dilihat dari nilai rata-rata yang diperoleh 13 orang guru juga terjadi peningkatan, yaitu pada siklus I rata-rata yang diperoleh hanya 64,72 menjadi 74,53 pada siklus II. terjadi peningkatan 9,81\%.
\end{abstract}

\section{Kata Kunci : Supervisi Akademik, Kompetensi Pedagogik dan Guru}

\section{PENDAHULUAN}

Sekolah merupakan salah satu organisasi pendidikan yang dapat dikatakan sebagai wadah untuk mencapai tujuan pembangunan nasional. Keberhasilan tujuan pendidikan di sekolah tergantung pada sumber daya manusia yang ada di sekolah tersebut yakni: kepala sekolah, guru, siswa, pegawai tata usaha, dan tenaga kependidikan lainnya. Selain itu harus didukung oleh sarana dan prasarana yang memadai. Guru merupakan salah satu komponen yang sangat menentukan untuk terselenggaranya proses pendidikan. Hal tersebut sesuai dengan tujuan pembangunan nasional dalam meningkatkan kualitas sumber daya manusia agar menjadi masyarakat Indonesia yang maju berdasarkan Pancasila. Keberadaan guru merupakan pelaku utama sebagai fasilitator penyelenggaraan proses belajar siswa. Oleh karena itu, kehadiran dan profesionalisme guru sangat berpengaruh dalam mewujudkan tujuan pendidikan nasional.

Selanjutnya, fungsi dan tugas guru sebagai tenaga profesional menyandang persyaratan tertentu sebagaimana tertuang didalam Undang-Undang Republik Indonesia Nomor 20 Tahun 2003 tentang Sistem Pendidikan Nasional dalam pasal 39 (1) dan (2) dinyatakan bahwa: "Tenaga kependidikan bertugas melaksanakan administrasi, pengelolaan, pengembangan, pengawasan, dan pelayanan teknis untuk menunjang proses pendidikan pada satuan pendidikan. Pendidik merupakan tenaga profesional yang bertugas merencanakan dan melaksanakan proses pembelajaran, menilai hasil pembelajaran, melakukan 
pembimbingan dan pelatihan, serta melakukan penelitian dan pengabdian kepada masyarakat, terutama bagi pendidik pada perguruan tinggi."

Guru memiliki peran yang penting, merupakan posisi strategis, dan bertanggungjawab dalam pendidikan nasional. "Tugas guru sebagai profesi meliputi: mendidik, mengajar dan melatih" ( Usman Uzer, 2002:7). Mendidik berarti meneruskan dan mengembangkan nilai-nilai hidup. Sedangkan mengajar berarti meneruskan dan mengembangkan ilmu pengetahuan dan teknologi. Melatih berarti mengembangkan keterampilan-keterampilan pada siswa. Untuk dapat melaksanakan tugas dan tanggung jawab di atas, seorang guru dituntut memiliki beberapa kemampuan dan keterampilan.

Lebih lanjut Prajudi Atmosudirdjo (1982:60) dalam Martinis Yamin \& Maisah (2010:26) menyebutkan bahwa guru memiliki peran yag sangat besar dalam pendidikan, di pundaknya dibebani suatu tanggung jawab atas mutu pendidikan. Maka dari itu guru harus mengembangkan dirinya dengan meningkatkan kompetensi dan kinerjanya.

Tugas utama guru adalah membimbing, membantu, mengarahkan peserta didik kedewasaaannya. Hal ini sejalan dengan pendapat Martinus Yamin \& Maisah, (2010:87) bahwa kinerja guru menyangkut seluruh aktivitas yang ditunjukkan oleh tenaga pengajar dalam tanggungjawabnya sebagai seorang yang mengemban suatu amanat dan tanggung jawab untuk mendidik, mengajar, membimbing, mengarahkan, dan memandu peserta didik dalam rangka menggiring perkembangan peserta didik kearah kedewasaan mental-spiritual maupun fisikbilogis.

Guru merupakan faktor yang paling dominan, karena ditangan gurulah keberhasilan pembelajaran dapat dicapai. Kualitas mengajar guru secara langsung maupun tidak langsung dapat mempengaruhi kualitas pembelajaran. Guru harus mampu berperan sebagai desainer (perencana), implementor (pelaksana), dan evaluator (penilai) kegiatan pembelajaran. Peran dan fungsi guru sangat menentukan keberhasilan dalam usaha peningkatan mutu pendidikan . Untuk itu guru sebagai agen pembelajaran dituntut memiliki kinerja yang baik.

Namun kenyataannya berdasarkan hasil observasi awal dan dokumen hasil supervisi yang ada, didapatkan informasi kinerja guru dalam (1) menyusun RPP; (2) penggunaan RPP dalam kegiatan pembelajaran; dan (3) evaluasi hanya $50 \%$ yang dapat dilakukan, dengan demikian dapat dikatakan kinerja guru belum maksimal.

Berdasarkan masalah tersebut di atas maka diperlukan supervisi akademik Kepala Sekolah untuk meningkatkan kinerja guru dalam mengelola pembelajaran. Peranan dan fungsi Kepala Sekolah sangat diperlukan dalam meningkatkan kinerja guru. Peranan Kepala Sekolah ialah bentuk perilaku yang diharapkan pada setiap orang untuk menjalankan fungsinya.

Berdasarkan uraian di atas tugas Kepala Sekolah yang dimaksud adalah yaitu sebagai supervisor meliputi: tugas merencanakan program supervisi, melaksanakan supervisi terhadap guru dengan menggunakan pendekatan dan teknik supervisi yang tepat serta menindaklanjuti hasil supervisi terhadap guru dalam pengelolaan pembelajaran. Beberapa alasan yang mendasari pentingnya supervisi yakni: (1) membantu guru untuk senantiasa memperbaiki dan meningkatkan kualitas proses pembelajaran; (2) mendiagnosis dan membantu memecahkan masalah-masalah pembelajaran; (3) membantu guru mengembangkan keterampilan dalam menggunakan strategistrategi pembelajaran; dan (4) membantu guru mengembangkan diri secara terus menerus dalam karir dan profesi secara mandiri.

Program pembinaan personil di sekolah baik guru atau staf lainnya oleh kepala sekolah di bidang pendidikan disebut supervisi pendidikan. Istilah supervisi sering diidentikkan dengan istilah pembinaan (Depdiknas, 1996 : 4). Pengertian supervisi dari segi etimologi berasal dari kata super, artinya atas, sedangkan visi diartikan melihat. 
Dengan demikian supervisi berarti melihat dari atas. Secara etimologi supervisi diartikan melihat dari atas, maka praktekpraktek supervisi lebih banyak mengarah ke inspeksi , kepenilikan dan kepengawasan. Apa yang disebut sebagai supervisi pada kenyataannya adalah inspeksi (Ali Imron, 1995 : 10). Secara terminologis supervisi sering diartikan sebagai serangkaian usaha memberikan bantuan kepada guru, terutama bantuan yang berwujud layanan profesional yang dilakukan oleh kepala sekolah, penilik sekolah dan pengawas serta pembina lainnya untuk meningkatkan proses dan hasil belajar (Ali Imron,1995 : 11) dalam Made Pidarta (1992 : 5) bahwa : Supervisi adalah proses pembimbingan dari pihak atasan kepada guru-guru dan para personalia sekolah lainnya yang langsung menangani belajar siswa, untuk memperbaiki situasi belajar mengajar, agar para siswa dapat belajar secara efektif dengan prestasi belajar yang semakin meningkat. Ngalim Purwanto (1998:76) menjelaskan bahwa : "Supervisi adalah suatu aktivitas pembinaan yang direncanakan untuk membantu para guru dan pegawai sekolah lainnya dalam melakukan tugas mereka secara efektif".

Berdasarkan beberapa pendapat di atas dapat dirumuskan bahwa supervisi adalah layanan dan bantuan yang terencana diberikan kepala sekolah kepada guru-guru dan para staf sekolah lainnya agar mereka dapat meningkatkan kemampuannya untuk mengembangkan situasi belajar mengajar yang lebih baik demi tercapainya tujuan pendidikan yang lebih efektif dan efeisien.

Peningkatan profesionalisme guru dalam mengajar adalah melalui supervisi akademik. Supervisi akademik adalah serangkaian kegiatan membantu guru mengembangkan kemampuannya mengelola proses pembelajaran untuk mencapai tujuan pembelajaran ( Daresh,1989, Clicman, et al:2007). Selanjutnya ditegaskan lagi oleh Dadang Suhardan (2010:13), bahwa masalah mutu pembelajaran, menyangkut masalah yang sangat esensial yaitu masalah kualitas mengajar yang dilakukan guru harus mendapat pengawasan profesional dan pembinaan terus menerus dan berkelanjutan dari supervisor untuk memperbaiki pembelajaran. Dengan demikian, esensi supervisi akademik itu sama sekali bukan menilai kinerja guru dalam mengelola proses pembelajaran, melainkan membantu guru mengembangkan

kemampuan profesionalismenya.

Sasaran supervisi akademik antara lain membantu guru dalam (1) merencanakan kegiatan pembelajaran dan atau bimbingan,(2) melaksanakan kegiatan pembelajaran/bimbingan, (3) menilai proses dan hasil pembelajaran /bimbingan, (4) memanfaatkan hasil penilaian untuk peningkatan layanan pembelajaran/bimbingan, (5) memberikan umpan balik secara tepat dan teratur, terus menerus pada siswa, (6) melayani siswa yang mengalami kesulitan belajar, (7) Memberikan bimbingan belajar pada siswa, (8) menciptakan lingkungan belajar yang menyenagkan, (9) mengembangkan dan memanfaatkan alat bantu dan media pembelajaran dan atau bimbingan, (10) memanfaatkan sumber-sumber belajar, (11) mengembangkan interaksi pembelajaran/bimbingan (metode, strategi, teknik, model, pendekatan dan-lain) yang tepat dan berdaya guna, (12) melakukan penelitian praktis bagi perbaikan pembelajaran/bimbingan, dan (13) mengembangkan inovasi pembelajaran/bimbingan.

Depdiknas (2004:4) kompetensi diartikan "sebagai pengetahuan, keterampilan, dan nilai-nilai dasar yang direfleksikan dalam kebiasaan berpikir dan bertindak" .Secara sederhana kompetensi diartikan seperangkat kemampuan yang meliputi pengetahuan, sikap, nilai dan keterampilan yang harus dikuasai dan dimiliki seseorang dalam rangka melaksanakan tugas pokok, fungsi dan tanggung jawab pekerjaan dan/atau jabatan yang disandangnya (Nana Sudjana 2009:1)

Nurhadi (2004:15) menyatakan "kompetensi merupakan pengetahuan, keterampilan, dan nilai-nilai dasar yang direfleksikan dalam kebiasaan berpikir dan 
bertindak". Selanjutnya menurut para ahli pendidikan McAshan (dalam Nurhadi 2004:16) menyatakan "kompetensi diartikan Sebagai pengetahuan, keterampilan, dan kemampuan yang dikuasai seseorang sebagai pengetahuan, keterampilan, dan kemampuan yang dikuasai seseorang yang telah menjadi bagian dari dirinya, sehingga dapat melakukan perilaku-perilaku koqnitif, afektif, dan psikomotor dengan sebaik-baiknya.

Kompetensi diartikan sebagai pengetahuan, keterampilan, dan nilai-nilai dasar yang direfleksikan dalam kebiasaan berfikir dan bertindak (dalam Suparlan) Arti lain dari kompetensi adalah spesifikasi dari pengetahuan, keterampilan, dan sikap yang dimiliki seseorang serta penerapannya di dalam pekerjaan, sesuai dengan standar kinerja yang dibutuhkan oleh lapangan.

Berdasarkan pendapat di atas dapat disimpulkan Kompetensi adalah sebagai suatu kecakapan untuk melakukan sesuatu pekerjaan berkat pengetahuan, keterampilan ataupun keahlian yang dimiliki untuk melaksanakan suatu pekerjaan.

Undang-Undang Guru dan Dosan No.14 Tahun 2005 Pasal 8 menyatakan" guru wajib memiliki kualifikasi akademik, kompetensi, sertifikat pendidik, sehat jasmani dan rohani, serta memiliki kemampuan untuk mewujudkan tujuan pendidikan nasional". Dari rumusan di atas jelas disebutkan pemilikan kompetensi oleh setiap guru merupakan syarat yang mutlak harus dipenuhi oleh guru. Dengan demikian, kompetensi yang dimiliki oleh setiap guru akan menunjukkan kualitas guru yang sebenarnya.

Selanjutnya pasal 10 menyebutkan empat kompetensi yang harus dimiliki oleh guru yakni (1) Kompetensi pedagogik, (2) kompetensi kepribadian, (3) kompetensi sosial, dan (4) kompetensi profesional. Kompetensi tersebut akan terwujud dalam bentuk penguasaan pengetahuan, keterampilan, maupun sikap profesional dalam menjalankan fungsi sebagai guru.

Berdasarkan beberapa definisi di atas dapat disimpulkan Standar Kompetensi guru adalah suatu pernyataan tentang kriteria yang dipersyaratkan, ditetapkan dalam bentuk penguasaan perangkat kemampuan yang meliputi pengetahuan, sikap, nilai dan keterampilan bagi seorang tenaga kependidikan sehingga layak disebut kompeten. Standar Kompetensi guru dipilah ke dalam tiga komponen yang saling kait mengait, yakni 1) pengelolaan pembelajaran, 2) Pengembangan profesi, dan 3) penguasaan akademik. Komponen pertama terdiri atas empat kompetensi, komponen kedua memiliki satu kompetensi, dan komponen ketiga memiliki dua kompetensi. Dengan demikian, ketiga komponen tersebut secara keseluruhan meliputi tujuh kompetensi dasar, yaitu: 1) penyusunan rencana pembelajaran, 2) pelaksanaan interaksi belajar mengajar, 3) penilaian prestasi belajar peserta didik, 4) pelaksanaan tindak lanjut hasil penilaian prestasi belajar peserta didik, 5) pengembangan profesi, 6) pemahaman wawasan kependidikan, dan 7) penguasaan bahan kajian akademik ( sesuai dengan mata pelajaran yang diajarkan).

Selanjutnya Peraturan Pemerintah (PP) Nomor 19 Tahun 2005 tentang Badan Standar Nasional Pendidikan (BSNP) menegaskan bahwa pendidik (guru) harus memiliki kompetensi sebagai agen pembelajaran pada jenjang pendidikan dasar dan menengah serta pendidikan anak usia dini. Arahan normatif tersebut yang menyatakan bahwa guru sebagai agen pembelajaran menunjukkan pada harapan, bahwa guru merupakan pihak pertama yang paling bertanggung jawab dalam pentransferan ilmu pengetahuan kepada peserta didik dan juga harus menguasai kompetensi pedagogik, kepribadian, profesional dan sosial. Hal ini dipertegaskan lagi dengan Permendiknas No.16 tahun 2007 menyebutkan kompetensi yang dimiliki guru ada empat yaitu Kompetensi Pedagogik, Profesional, Keperibadian dan sosial. Diantara empat kompetensi ini, yang akan dibahas adalah kompetensi pedagogik guru.

Kompetensi pedagogik, merupakan kemampuan dalam pengelolaan peserta didik meliputi pemahaman wawasan guru akan 
ladasan dan filsafat pendidikan, pemahaman potensi dan keberagaman peserta didik. Kompetensi pedogogik meliputi: (1) Menguasai karakteristik peserta didik, (2) Menguasai teori belajar dan prinsip-prinsip pembelajaran yang mendidik,

Pengembangan Kurikulum, (4) Kegiatan pembelajaran yang mendidik, pengembangan potensi peserta didik, (6) komunikasi dengan peserta didik, Penilaian dan evaluasi.

Lebih lanjut Permendiknas No.16 Tahun 2007 menyebutkan Kompetensi Pedagogik terdiri dari 10 Kompetensi inti yaitu (1) Menguasai karakteristik peserta didik dari aspek fisik, moral, spritual, sosial, kultural, emosional dan intelektual, (2) Menguasai teori belajar dan prinsip-perinsip pembelajaran yang mendidik,

Mengembangkan kurikulum yang terkait dengan mata pelajaran yang diampu, (4) Menyelenggarakan pembelajaran yang mendidik, (5) Memanfaatkan teknologi informasi dan komunikasi untuk kepentingan pembelajaran, (6) Memfasilitasi pengembangan potensi peserta didik untuk mengaktualisasikan berbagai potensi yang dimiliki, (7) Berkomunikasi secara efektif, empatik, dan santun dengan peserta didik, (8) Menyelenggarakan penilaian dan evaluasi proses dan hasil belajar, (9) Memanfaatkan hasil penilaian dan evaluasi untuk kepentingan pembelajaran, (10) Melakukan tindakan reflektif untuk peningkatan kualitas pembelajaran.

Kompetensi kepribadian, guru sebagai teladan bagi murid-muridnya harus memiliki sikap dan kepribadian utuh yang dapat dijadikan tokoh panutan idola dalam seluruh segi kehidupannya. Kompetensi profesional, tugas utama mendidik, mengajar, membimbing, mengarahkan, melatih, menilai dan mengevaluasi peserta didik. Kompetensi sosial, kemampuan guru untuk berkomunikasi dan bergaul secara efektif dengan peserta didik, sesama pendidik, tenaga kependidikan, orang tua/wali peserta didik dan masyarakat sekitar..

Guru yang bermutu niscaya mampu melaksanakan pendidikan, pengajaran dan pelatihan yang efektif dan efisien. Mereka diyakini mampu memotivasi siswa untuk mengoptimalkan potensinya dalam kerangka pencapaian standar pendidikan yang ditetapkan. Kemampuan mengajar guru yang sesuai dengan tuntutan standar tugas yang diemban memberikan efek positif bagi hasil yang ingin dicapai seperti perubahan hasil akademik siswa, sikap siswa, keterampilan siswa, dan perubahan pola kerja guru yang semakin meningkat. Sekolah mempunyai peranan yang sangat besar dalam mencerdaskan kehidupan bangsa dengan memberikan pelayanan yang baik kepada siswa. Sebelum memberikan pelayanan kepada siswa maka guru yang terlibat dalam proses belajar mengajar juga harus diperhatikan kinerjanya.

Untuk mencapai maksud tersebut di atas peranan dan fungsi kepala sekolah sangat diperlukan dalam mengelola sekolah. Peranan kepala sekolah ialah bentuk prilaku yang diharapkan pada setiap orang untuk menjalankan fungsinya. Fungsi kepala sekolah sebagai seorang manejer dituntut untuk mampu mengelola sekolah dengan baik dan mampu menyusun kurikulum sekolah sebagai pedoman penyelenggaraan kegiatan pembelajaraan untuk mencapai tujuan pendidikan nasional. Hal ini dipertegaskan lagi oleh Permendiknas No.13 Tahun 2007 tentang standar kompetensi kepala sekolah menyebutkan " terdapat 5 kompetensi yang harus dimiliki oleh kepala sekolah yaitu (1) Kepribadian, Manajerial, (3) Kewirausahaan, Supervisi, (5) Sosial Dari keempat kompetensi di atas yang akan dibahas adalah supervisi, yang ada hubungan dengan judul penelitian ini.

Supervisi yang dimaksud Dalam permendiknas No.13 adalah (1) Merencanakan program supervisi akademik dalam rangka peningkatan profesionalisme guru, (2) Melaksanakan supervisi akademik terhadap guru dengan menggunakan pendekatan dan teknik supervisi yang tepat, (3) Menindaklanjuti hasil supervisi akademik terhadap guru dalam rangka peningkatan professional guru. 
Kepala sekolah berasal dari dua kata yaitu kepala dapat diartikan pimpinan atau ketua dalam suatu organisasi atau sebuah lembaga, sedang kata sekolah adalah sebuah lembaga di mana terjadi tempat menerima dan memberi. Berdasarkan penggabungan dua kata tersebut dapat didefinisikan bahwa kepala sekolah adalah pemimpin sebuah lembaga yang menjadi tempat menerima dan memberi pelajaran.

Wahjosumidjo

mendefinisikan bahwa "kepala sekolah seorang tenaga fungsional guru yang diberi tugas untuk memimpin suatu sekolah dimana diselenggarakan proses belajar mengajar, atau tempat di mana terjadi interaksi antara guru yang memberi pelajaran dan murid yang menerima pelajaran". Selanjutnya Permendiknas No.28 tahun 2010 tentang penugasan guru sebagai kepala sekolah/madrasah menyatakan "Kepala sekolah/madrasah adalah guru yang diberi tugas tambahan untuk memimpin sekolah".

Berdasarkan definisi di atas dapat dirumuskan bahwa kepala sekolah adalah tenaga fungsional guru yang diberi tugas sebagai pemimpin suatu sekolah yang berperan sebagai manajer di lembaga dimana terjadi interaksi proses belajar mengajar.

Untuk mewujudkan tujuan di atas diperlukan seorang pemimpin atau kepala sekolah yang mampu mengelola sekolah dengan baik dan memiliki motivasi kerja yang tinggi, serta mampu menciptakan lingkungan sekolah yang kondusif dapat mendukung kinerja guru yang berakhir pada peningkatan prestasi siswa.

Kepala sekolah sebagai pimpinan tertinggi yang sangat berpengaruh dan menentukan kemajuan sekolah harus memiliki kemampuan administrasi, memiliki komitmen tinggi, dan luwes dalam melaksanakan tugasnya. Kepemimpinan kepala sekolah yang baik harus dapat mengupayakan peningkatan kinerja guru melalui program pembinaan kemampuan tenaga kependidikan. Oleh karena itu kepala sekolah harus mempunyai kepribadian atau sifat-sifat dan kemampuan serta keterampilan-keterampilan untuk memimpin sebuah lembaga pendidikan.

Hal tersebut menjadi lebih penting sejalan dengan semakin kompleksnya tuntutan tugas kepala sekolah, yang menghendaki dukungan kinerja yang semakin efektif dan efisien. Davi F Salisbury (1996:149) dalam Suryadi (2009:70) menjelaskan "without quality leadership and skillful management, even the ideas are never implemented. Witouth good management and on going support for their leaders, those lower in the organization become disillusioned in time, case to continue the change effort". Upaya perbaikan mutu dalam suatu organisasi sangat ditentukan oleh mutu kepemimpinan dan manajemen yang efektif. Dukungan dari bawah hanya akan muncul secara berkelanjutan ketika pimpinannya benarbenar bermutu atau unggul.

Berdasarkan fakta di lapangan bahwa kepemimpinan kepala sekolah sangat penting dan akan berpengaruh terhadap pelaksanaan tugas guru di sekolah yang akhirnya akan berpengaruh juga pada pencapaian tujuan pendidikan yang diharapkan. Selain itu dengan motivasi kerja kepala sekolah akan dapat mempengaruhi peningkatan kinerja guru dan tenaga pendidik lainnya di sekolah.

Kepala sekolah yang berhasil apabila mereka memahami keberadaan sekolah sebagai organisasi yang komplek dan unik serta mampu melaksanakan peranan kepala sekolah sebagai seorang yang diberi tanggung jawab untuk memimpin sekolah. Dalam mengelola sekolah, kepala sekolah memiliki peran yang sangat besar. Kepala sekolah merupakan motor penggerak, penentu arah kebijakan menuju sekolah dan pendidikan secara luas.

Kepala sekolah merupakan orang atau personil kependidikan yang memiliki peran besar dalam mencapai keberhasilan pengelolaan suatu sekolah, sedangkan guru berada posisi lain yang berperan besar dalam keberhasilan proses belajar mengajar di dalam kelas disamping peran siswa, karyawan sekolah dan juga orang tua siswa. Kualitas kepemimpinan kepala sekolah yang didalamnya terdapat juga kepribadian, 
ketrampilan dalam mengelola sekolah termasuk dalam menangani masalah yang timbul disekolah, gaya kepemimpinan serta kemampuan menjalin hubungan antar manusia sangat menentukan atau memiliki pengaruh yang besar terhadap kualitas proses belajar dan mengajar di sekolah.

Dalam hal ini keberhasilan kepala sekolah dalam memimpin sekolah akan tampak dari apa yang dikerjakannya. Hal ini penting untuk dikedepankan karena apa yang telah dikerjakan kepala sekolah melalui kebijakan yang telah ditetapkan akan mempengaruhi kondisi fisik dan psikis para guru, siswa dan karyawan sekolah. Guru akan dapat melaksanakan tugas dengan penuh rasa tanggung jawab apabila ia merasa puas terhadap kepemimpinan kepala sekolah. Oleh sebab itu seorang kepala sekolah dalam memimpin agar tujuan yang telah ditetapkan dapat tercapai dengan baik ia juga harus memperhatikan secara kultural, baik bagi guru, siswa, karyawan sekolah, orang tua siswa serta lingkungan masyarakat.

Menurut Mulyasa, dalam Deni Koswara (2008:57) kepemimpinan seseorang sangat berkaitan dengan kepribadian, dan keperibadian kepala sekolah sebagai pemimpin akan tercermin dalam sifat-sifat yang jujur, percaya diri, tanggung jawab, berani mengambil resiko dan keputusan, berjiwa besar, emoso yang stabil dan teladan.

Selanjutnya menurut Mulyono ( 2008:143) kepemipinan kepala sekolah merupakan ruh yang menjadi pusat sumber gerak organisasi untuk mencapai tujuan dalam meningkatkan kesempatan untuk mengadakan pertemuan secara efektif dengan para guru dalam situasi yang kondusif. Perilaku kepala sekolah harus dapat mendorong kinerja para guru dengan menunjukkan rasa bersahabat, dekat dan penuh pertimbangan terhadap para guru, baik sebagai individu maupun sebagai kelompok.

Berdasarkan uraian tersebut di atas, seorang kepala sekolah pada hakikatnya adalah seorang perencana, organisator, pemimpin dan seorang pengendali. Keberadaan seorang kepala sekolah diperlukan untuk mencapai suatu tujuan yang telah ditetapkan dimana di dalam organisasi yang di pimpinnya berkembang berbagai macam pengetahuan serta organisasi yang menjadi tempat untuk membina dan mengembangkan karir sumber daya manusia. Kepemimpinan kepala sekolah yang efektif dapat dilihat berdasarkan kriteria, mampu memberdayakan guru untuk melaksanakan proses pembelajaran dengan baik, lancar dan produktif. Kepala sekolah dapat menjelaskan tugas dan pekerjaannya sesuai waktu yang telah ditetapkan, mampu membangun hubungan yang harmonis dengan guru dan masyarakat dalam rangka mewujudkan tujuan sekolah.

Menurut Wahjosumidjo ( 2008:102 ) bahwa kepemimpinan kepala sekolah terdiri dari :

kepemimpinan yang berorientasi pada tugas (struktur initiang) yang meliputi : mengutamakan pencapaian tujuan, menilai pelaksanaan tugas bawahan, menetapkan batas-batas waktu pelaksanaan tugas, menetapkan standar tertentu terhadap tugas bawahan, memberi petunjuk-petunjuk kepada bawahan, melakukan pengawasan secara ketat terhadap tugas.

kepemimpinan yang berorientasi pada hubungan manusia yang meliputi : melibatkan bawahan dalam pengambilan keputusan, bersikap bersahabat, membina hubungan kerjasama dengan baik, membeerikan dukungan terhadap bawahan, menghargai ide atau gagasan, memberi kepercayaan terhadap bawahan.

Selanjutnya Wahjosumidjo (1994 : 83) mendefinisikan bahwa "kepala sekolah seorang tenaga fungsional guru yang diberi tugas untuk memimpin suatu sekolah dimana diselenggarakan proses belajar mengajar, atau tempat di mana terjadi interaksi antara guru yang memberi pelajaran dan murid yang menerima pelajaran.

Berdasarkan definisi supervisi dan kepala sekolah di atas berarti supervisi kepala sekolah bukan hanya sekedar control untuk melihat apakah semua kegiatan yang dilaksanakan sudah sesuai dengan program atau belum, tetapi lebih dari itu supervisi merupakan tugas kepala sekolah untuk 
membina guru, agar guru dapat meningkatkan kualitas diri dalam arti meningkatkan kinerjanya yang ditandai adanya peningkatan kemampuan dan mengembangkan proses belajar mengajar yang lebih effektif.

\section{METODE PENELITIAN}

Setting dalam penelitian ini meliputi: (1) Subjek dan Objek penelitian, (2) Waktu Penelitian, (3) Siklus Penelitian Tindakan Sekolah, (4) Sumber Data, (5) Teknik dan alat pengumpul Data sebagai berikut: a) Subjek dan Objek Penelitian adalah 13 orang guru yang terdiri dari 5 (lima) orang guru laki-laki dan 8 (delapan) orang guru perempuan di SMAN 2 Bengkayang, b) waktu penelitian bulan Januari s.d April pada semester II Tahun Pelajaran 2018/2019, c) Penelitian dilaksanakan melalui dua siklus, $\mathrm{d}$ ) Sumber data adalah dokumen supervisi akademik, e) Teknik dan alat pengumpul data yaitu melihat kemampuan guru melaksanakan proses pembelajaran di kelas, alat pengumpul data meliputi observasi, dan wawancara . Observasi yaitu melaksanakan pengamatan secara langsung terhadap guru dalam proses mengajar di kelas menggunakan instrumen supervisi pembelajaran. Wawancara yaitu berdialog langsung dengan subjek penelitian sebelum dan sesudah observasi untuk mendapatkan informasi langsung dari yang bersangkutan. Wawancara sebelum observasi dimaksudkan untuk mempersiapkan guru untuk melaksanakan pembelajaran. Sedangkan wawancara setelah penelitian adalah untuk menyampaikan hal-hal penting yang harus diperbaiki untuk dilaksanakan pada siklus berikutnya atau sudah dilaksanakan dalam pembelajaran untuk ditingkatkan. Adapun alat pengumpul data yang digunakan oleh peneliti adalah instrumen pengumpul data berupa instrumen observasi aktifitas mengajar guru.

Hal-hal penting yang harus diperhatikan dalam penelitian Tindakan Sekolah , menurut Sudarsono, FX (1:2) Yakni (1) Rencana yaitu tindakan apa yang akan dilakukan untuk meningkatkan kemampuan pedagogik guru. Solusinya yaitu dengan melakukan wawancara dengan guru, dengan menyiapkan lembar wawancara, (2) Pelaksanaan: apa yang dilakukan oleh peneliti sebagai upaya meningkatkan kemampuan guru dalam melaksanakan kompetensi pedagogik, (3) Observasi yaitu melaksanakan pengamatan secara langsung terhadap guru dalam proses mengajar di kelas menggunakan instrumen supervisi pembelajaran. (4) Refleksi yakni; peneliti mengkaji, melihat dan mempertimbangkan hasil atau dampak dari tindakan yang telah dilakukan. Berdasarkan hasil dari refleksi ini, peneliti bersama guru melaksanakan perbaikan terhadap proses mengajar di kelas.

Prosedur penelitian adalah suatu rangkaian tahap-tahap penelitian dari awal sampai akhir. Penelitian ini merupakan proses pengkajian sistem berdaur sebagaimana kerangka berpikir yang dikembangkan oleh Suharsimi Arikunto dkk (2006;74). Prosedur ini mencakup tahaptahap: (1) perencanaan , (2) Pelaksanaan,, (3) pengamatan, dan (4) Refleksi. Keempat kegiatan tersebut saling terkait dan secara urut membentuk sebuah siklus. Penelitian yang bersiklus, artinya penelitian dilakukan secara berulang dan berkelanjutan sampai tujuan penelitian dapat tercapai

\section{HASIL DAN PEMBAHASAN}

Hasil penilaian kemampuan guru dalam melaksanakan pembelajaran di kelas diketahui terdapat peningkatan rata-rata secara signifikan dari siklus I ke siklus II.

Pada siklus I kemampuan guru melaksanakan pembelajaran masih rendah hal ini dibuktikan dengan nilai akhir yang diperoleh setiap, dan nilai rata-rata kemampuan guru dari hasil observasi pembelajaran dimana guru yang memperoleh skor nilai 1 (kurang) dengan rentang nilai dibawah 55\% adalah 1 orang guru, skor nilai 2 (cukup) dengan rentang nilai 55\%-69\% adalah 10 orang guru, skor nilai 3 (baik) rentang nilai 70\%-85\% adalah 2 orang guru, dan tidak ada guru yang memperoleh skor nilai 4 (sangat baik).

Pada siklus II terjadi peningkatan kemampuan mengajar guru yang dari siklus 
I, pada siklus guru yang memperoleh skor nilai 2 (cukup) dengan rentang nilai 55\%$69 \%$ adalah 3 orang, dan skor nilai 3 (baik) rentang nilai $70 \%-.85 \%$ adalah 10 orang guru, dan tidak ada guru yang memperoleh skor nilai 1 (kurang) dan skor nilai 4 (sangat baik).

Dilihat dari nilai rata-rata yang diperoleh 13 orang guru juga terjadi peningkatan, yaitu pada siklus I rata-rata yang diperoleh hanya 64,72 menjadi 74,53 pada siklus II.

Berdasarkan pemaparan diatas, dari dua siklus kegiatan penelitian tindakan sekolah yang dilakukan dapat diketahui bahwa terjadi peningkatan kemampuan guru dalam melaksanakan pembelajaran dari memperoleh nilai akhir kurang dan cukup pada akhirnya semua guru yang diobservasi memperoleh nilai akhir baik.

Hal ini menunjukan bahwa dengan dilakukan supervisi akademik secara rutin terhadap guru dalam melaksanakan pembelajaran di sekolah sangat efektif dalam meningkatkan kemampuan mengajar guru SMAN 2 Bengkayang pada semester 2 tahun pelajaran 2018/2019

\section{KESIMPULAN DAN SARAN Kesimpulan}

Berdasarkan hasil penelitian tindakan sekolah yang dilakukan, dapat dibuat kesimpulan sebagai berikut : pelaksanaan supervisi akademik oleh kepala sekolah dapat meningkatkan pedogogik guru, ini dapat dilihat Setelah diadakan supervisi akademik, terjadi perubahan kualitas guru dalam melaksanakan pembelajaran di kelas, hasil pengamatan pada siklus 1 terhadap 13 orang guru yang memperoleh nilai baik 2 orang, nilai cukup 10 orang dan nilai kurang 1 orang, rata-rata nilai akhir diperoleh 64,72 kategori (Cukup) sedangkan pada siklus II hasil pengamatan terhadap 13 orang guru adalah 10 guru memperoleh nilai baik dan 3 orang guru memperoleh nilai cukup, rata -rata nilai akhir 74,53 kategori (baik). terjadi peningkatan dari siklus 1 ke siklus 2 yaitu sebesar $9,81 \%$

\section{Saran}

Pengawas sekolah hendaknya rutin melakukan supervisi terhadap guru. Guru harus mempersiapkan RPP, alat peraga, media yang tepat sebelum melaksanakan pembelajaran. Guru hendaknya menjaga kesehatan fisik dan mental agar dapat melaksanakan pembelajaran secara efektif. Guru hendaknya selalu melakukan inovasi untuk mengembangkan sistem pembelajaran untuk meningkatkan mutu pendidikan.

\section{DAFTAR RUJUKAN}

Arikunto.dkk.2006.Penelitian Tindakan Kelas.Jakarta:PT.Bumi Aksara dan Sinar Grafika Pffset Clickman 2007 dalam Juansih, Meningkatkan Kemamouan Guru Dalam Memotivasi Siswa melalui Supervisi Akademik, Jurnal Pendidikan Asosiasi Pengawas Sekolah Indonesia , Volume 3, Nomor 1 , Mei 2015.

Depdiknas : 1996. Petunjuk Peningkatan Mutu Pendidikan di Sekolah Dasar. Jakarta : Departemen Dalam Negeri RI Dirjen Pemerintah Umum dan Otonomi Daerah Kerjasama Departemen Pendidikan dan Kebudayaan Dirjen Pendidikan Dasar dan Menengah.

Depdiknas. 2004. Pedoman supervisi pengajaran. Direktorat Pendidikan Lanjutan Pertama Direktorat Jenderal Pendidikan.

Glickman, D. C. 1981. Developmental Supervision: Alternative Practices for Helping Teachers Improve Instruction. Association for Supervision and Curriculum Development.

Imron Ali. 1995 Pembinaan Guru Di Indonesia Malang: Pustaka Jaya.

Koswara, Deni.2008.Kebiasaan Kepala Sekolah Efektif. Bandung. Pribumi Mekar

Made Pidarta. 1992. Pemikiran Tentang Supervisi Pendidikan. Jakarta : Bumi Aksara. 
Mulyono.2008. Manajemen Adminstrasi \& Organisasi Pendidikan. Malang. Arruzzmedia.

Ngalim Purwanto 1988. Administrasi dan Supervisi Pendidikan. Bandung : Remaja Rodakarya

Nurhadi. 2004, Kurikulum 2004. Jakarta: PT Gramedia Widiasarana Indonesia

Peraturan Pemerintah (PP) Nomor 19 Tahun 2005 tentang Standar Nasional Pendidikan (BSNP)

Permendiknas RI No. 16 Tahun 2007a Tentang Standar Kualifikasi Akademik dan Kompetensi Guru Sekolah

Suhardan, Dadang.H. 2010. (Layanan Supervisi Profesional dalam Meningkatkan Mutu Pengajaran.

Wahjosumidjo. 1994. Kepemimpinan Kepala Sekolah. Jakarta: Raja Grafindo Persada. -2008. Kepemimpinan Kepala Sekolah.Jakarta. Raja Grafindo Persada.

Yamin, M. dkk. 2010. Standarisasi Kinerja Guru.Jakarta: Gaung Persada (GP Press).

Usman, U. 2002 Menjadi Guru Profesional. Bandung: PT Remaja Rosdakarya.
Permendiknas RI No. 13 Tahun 2007b Tentang Standar Kompetensi Kepala Sekolah

Permendiknas RI No. 28 Tahun 2010 Tentang Penugasan guru sebagai Kepala/Madrasah . Jakarta: Mendiknas.

Suparlan.2005. Menjadi Guru Efektif, Yogyakarta: Hikayat Publishing

Suryadi.2009.Manajemen Berbasis Sekolah Konsep dan Aplikasi. Bandung.Sarana Panca Karya Nusa.

Sudjana Nana. 2009. Standar Kompetensi Pengawas Dimensi dan Indikator. Jakarta : Binamitra Publishing

Undang Undang RI Nomor 20 Tahun 2003, Tentang Sistem Pendidikan Nasional. Jakarta: Direktorat Jenderal Pendidikan Dasar dan Menengah Bagian Proyek Penilaian Hasil Belajar Tahap Akhir Nasional.

Undang-Undang Republik Indonesia Nomor 14 Tahun 2005, Tentang Guru dan Dosen Balitbang Depdiknas, Statistik Pendidikan, jakarta: Balitbang Depdiknas. 